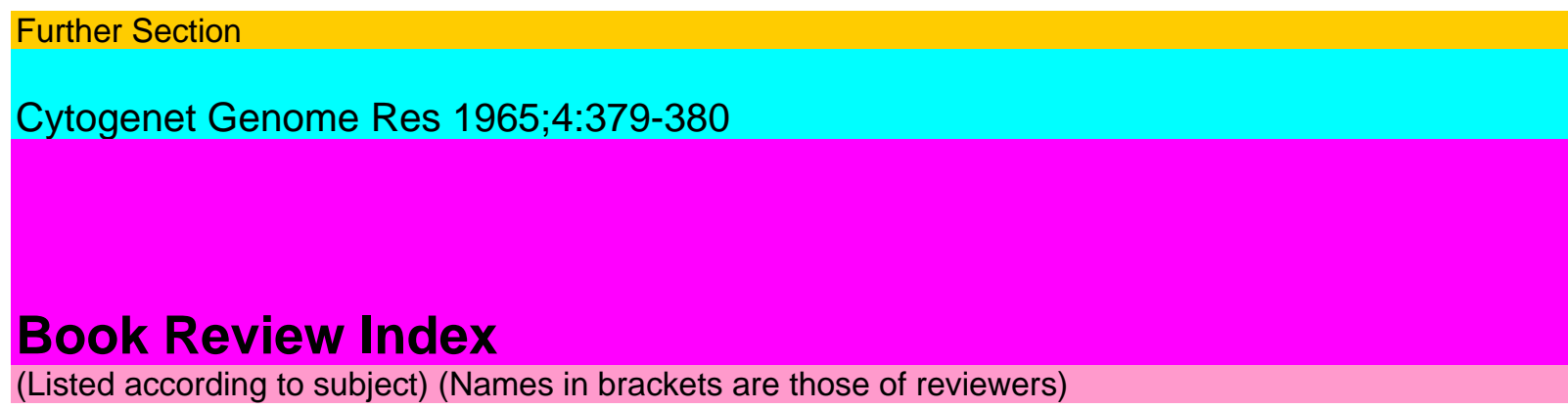

Carcinogenesis

Homburger, F. (editor): Progress in Experimental Tumor Research. Volume j. (P. C. Koller): 316

Homburger, F. (editor): Progress in Experimental Tumor Research. Volume 6. (P. C. Koller): 371

Lamerton, L. F. and Fry, R. J. M. (editors): Cell Proliferation. (V. Monesi): 74 Cytogenet Genome Res and Chromosome Aberrations

Gustavson, K.-H.: Down's Syndrome: A Clinical and Cytogenetical Investigation. (J. L. Hamerton): 207

Hall, B.: Mongolism in Newborns: A Clinical and Cytogenetic Study. (J. L. Hamerton): 207 Cytology

Butler, J. A. V.: The Life of the Cell. Its Nature, Origin and Development. (M. Fraccaro): 319

Hall, D. A. (editor): International Review of Connective Tissue Research. (A. T. Davey): 317

Harris, M.: Cell Culture and Somatic Variation. (M. Fraccaro): 319

Lamerton, L. F. and Fry, R. J. M. (editors): Cell Proliferation. (V. Monesi):

74 Zeuthen, E. (editor): Synchrony in Cell Division and Growth. (L. G. Lajtha): 75

Dictionary

Kenneth, J. H.: A Dictionary of Biological Terms. Pronunciation, Derivation and Definition of Terms in Biology, Botany, Zoology, Anatomy, Cytology, Genetics, Embryology, Physiology by I. F. Henderson and W. D. Henderson. 8th Edition. (M. Fraccaro): 79

Differentiation and Development

Butler, J. A. V.: The Life of the Cell. Its Nature, Origin and Development.

( M. Fraccaro): 319 Zeuthen, E. (editor): Synchrony in Cell Division and Growth. (L. G. Lajtha): 75

Epidemiology

Neel, J. V.; Shaw, Margery W. and Schull, W. J. (editors): Genetics and Epidemiology of Chronic Diseases. (M. Fraccaro): 317 Evolution De Beer, Sir Gavin : Charles Darwin. Evolution by Natural Selection

(A.W.F. Edwards): 76

Genetics (see also Cytogenet Genome Res)

Bresch, C: Klassische und molekulare Genetik. (C. Stern): 78

Cox, B. S.; Huizinga, J. and Artimov, V. (editors): Heredity and Variability of

Micro-organisms. Proceedings of the Moscow Conference, January 2J-26, 1962.

(E. Calef): 77 Harris, M.: Cell Culture and Somatic Variation. (M. Fraccaro): 319 Kalmus, H.: Genetics, 2nd Edition. (C. Barigozzi): 316 Lamerton, L. F. and Fry, R. J. M. (editors): Cell Proliferation. (V. Monesi): 74 Neel, J. V.; Shaw, Margery, W. and Schull, W. J. (editors) Genetics and

Epidemiology of Chronic Diseases. (M. Fraccaro): 317 Niermann, H.: Zwillingsdermatologie, (G. R. Fraser): 318 Williams, R. J.: Free and Unequal. The Biological Basis of Individual Liberty.

(G. R. Fraser): 78

380

\title{
Book Review Index
}

Histo- and Biochemistry

Manning, J. P.; Cavazos, L. F.; Feagans, W. M. and Turner, M. E.: Effects of Diethylstilbestrol on Beta-Glucuronidase Activity of Hamster Liver and Kidney: Histochemical, Biochemical and Biometrical Study. (Ü. Magrini): 76

History and Philosophy of Science

De Beer, Sir Gavin: Charles Darwin. Evolution by Natural Selection. (A.W.F.

Edwards): 76 Williams, R. J.: Free and Unequal. The Biological Basis of Individual Liberty.

(G. R. Fraser): 78

Immunology

Cruickshank, R. (editor): Modern Trends in Immunology-i. (Sylvia D. Lawler):

80 Kallos, P. and Waksman, B. H. (editors): Progress in Allergy. Volume p.

(K. Hirschhorn): 371

Microbiology

Cox, B. S.; Huizinga, J. and Artimov, V. (editors): Heredity and Variability

of Micro-organisms. Proceedings of the Moscow Conference, January 2J-26, 1962. 
(E. Calef): 77 Hayes, W.: The Genetics of Bacteria and their Viruses. Studies in Basic Genetics and

Molecular Biology. (O. Ciferri): 374 Zeuthen, E. (editor): Synchrony in Cell Division and Growth. (L. G. Lajtha):

75

Microcirculation

Harders, H. (editor): Second European Conference on Microcirculation, Pavia 1962. (V. Malamani): 79

Molecular Biology and Genetics

Bresch, C.: Klassische und molekulare Genetik. (C. Stern): 78

Clowes, R. C. (editor): Recent Research in Molecular Biology. (J. de Grouchy): 369

Hayes, W.: The Genetics of Bacteria and their Viruses. Studies in Basic Genetics and

Molecular Biology. (O. Ciferri): 374 Lamerton, L. F. and Fry, R. J. M. (editors): Cell Proliferation. (V. Monesi): 74 Zeuthen, E. (editor):

Synchrony in Cell Division and Growth. (L. G. Lajtha): 75 